\title{
建物の被害に対する地盤液状化の寄与度
}

—1964 年新潟地震による新潟市の建物の被害と復旧調査から—

$\begin{array}{lllll}\text { 正会員 } & \text { 望 } & \text { 月 } & \text { 利 } & \text { 男* } \\ \text { 正会員 } & \text { 宮 } & \text { 野 } & \text { 道 } & \text { 雄** }\end{array}$

1.はじめに

1964 年新潟地震における構造物の被害調查は各方面 で行われ，今日に至るまで砂質地盤の液状化のメカニズ ムおよび被害との関倸などに関する研究が続けられてい る。ここでは, 当時の新潟市における被害と復旧に関す る調查記録に，最近新たに行った調查資料を加え，鉄筋 コンクリート造などの建物の被害状況を再整理すること により，地盤の液状化が，この種の建物の被害にどの程 度の影響をおよぼしたがより量的に把握し，都市の地 震を対象とした被害子測のための一資料にする。

また，木造建物のように軽い構造物の被害に刘する液 状化の寄与度については, 当時, 重量構造物の被害が著 しかったこともあって，充分調查されたとは必らずしも いえない。ために，最近各地で行われている地震時被害 想定においても液状化をどの程度の危険度要因として評 価するかについて，量的根扰を欠いている。それ故，液 状化が木造建物にどの程度の被害を, どのような型で与 えたか，そして復旧が如何ように行われ，それに要した 費用は，などを住宅，個人商店を中心に現地で闑き込み を主体として調查した。地震後 10 年余経過しており, 記憶の薄れている心配は方ったが，その場所で地震を体 験し，かつ建物が居住者の持家であり，その復旧が自己 の分担でなされた場合にのみ調查を行うように限定した ため, かなり明快な回答が得られた。本報告は，以上の 調查結果をまとめたものであり，地震後の復旧状況を加 味した液状化地域における鉄筋コンクリート造および木 造建物群の確からしい被害率の推定などにその主眼をお いている。

\section{2. 鉄筋コンクリート造建物の被害とその復旧}

地震当時の新潟市に押ける $\mathrm{R} \mathrm{C}$ 造建物（SRC 造 9 棟 を含む)の総棟数は約 1530 棟と推定されている のらち著者らは当時, 250 棟に対し，実測を含む調查を 行った。これに，建設省建築研究所および住宅金融公庫 が実施した調查棟数を加光，ここでは 425 棟の資料につ いて以下幾つかの整理を行う。

\footnotetext{
* 東京都立大学工学部助手 工博 ** 同大学院生 工修
} （昭和 51 年 11 月 2 日本稿受理・討論期限昭和 52 年 10 月末日）
また，被災した鉄筋コンクリート造建物の復旧につい ての貴重な資料としては，文献 2）があるが，ここでは その記録に今回新たにアンケート調查を実施して得られ た資料を加え，復旧工法とそれ要した費用(被災金額) などの面から，その被害を考えてみる。

（1） R C造建物の被害状況の概略

前述したように，当時の新潟市には約 1530 棟の $\mathrm{R} \mathrm{C}$ 造建物があったといわれている。建築学会がまとめたと ころによれば， R C造建物の総被害棟数は，新潟市とそ の近郊で 232 棟 (SRC 造 2 棟を含む) である って，単純に被害棟数比率を求めれげ，約 $15.2 \%$ 程度 になる。ところで，この被圊比率の内訳は，必らずしも 明確ではないし，集計が 新潟市全域にわたっているた め，大規模な液状化が生じた範南内での状況が量的に表 わされていない。それ故ここでは上記の資料に基づ き,これらの点をやや詳細にまとめなおしてみる。

図一1 は，全調査建物のらち，基礎下端（值接基礎の 下底，〈い基礎の先端）付近の地層の地震前 $N$ 值のわ かっている 154 棟の建物の被害程度（不同沈下による 傾斜角）と，その約 $1.0 \mathrm{~m}$ 厚の平均 $N$ 值の関係を示 したものである。図は調查地域全体を対象としたもので あるが， $N$ 值 10 以上の地層に支持された建物の傾斜 は，著しく減じている。 $N$ 值 15 以上では， $1^{\circ}$.を越え る被害はほとんぞない。このグラフは，後述するような 限界 $N$ 值とそれによる軟弱層厚に基づく地城区分を行 っていないため， $N$ 值 10 以下でも無被害建物はかなり みられる。すなわち，図における $N$ 值の比較的低い地 層に支持された建物の被害程度の差異, 地域差が地盤構 成とこの地震による大規模な液状化発生条件との関係加 ら生じたものとして，特に注目される。

次に傾斜觕 (不同沈下量) と上部建物の損傷の関係に ついてまとめてみる。この関係は建物の規模, 形 (長辺, 短辺の比などによっても異なることが考兄られるため， 図一2（a)，(b) に示すように，それぞれ横軸に建築面 積, 建物の辺長比（二建物の長辺方向の長さ/同短辺方向 の長さ), 縱軸に傾斜角をとり,この座標上にラーメンに も亀裂がみられる建物は ×印で，壁あるいは他の建物な 


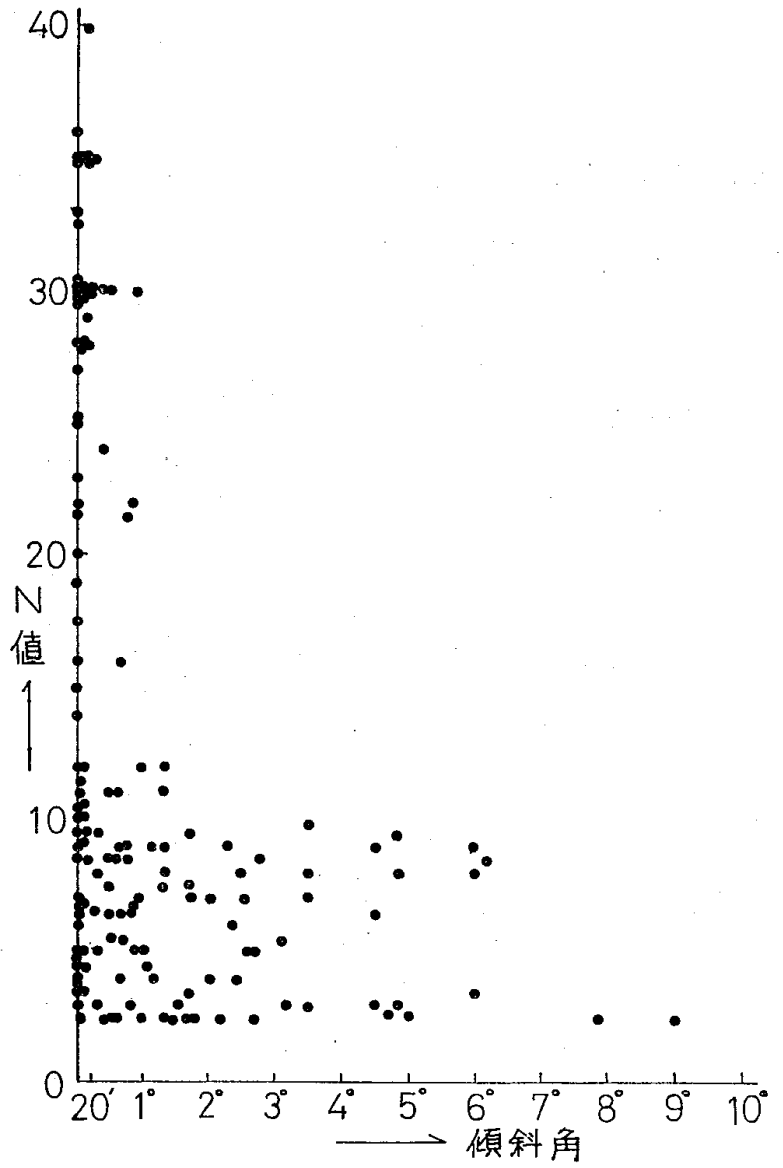

図一1建物の傾斜角と基濋下端付近の $N$ 值の関係

どの接合部等にのみ㝵裂が生じている建物を・印でプロ ットした。図一2（a）によれば小規模な建物を除き，壁 などに亀裂が生じた不同沈下量の下限は $20^{\prime}(\doteqdot 3 / 500)$, ラーメン材にまで亀裂が生じた同下限は $30^{\prime}(\div 4.5 / 500)$ であり，建築面積が $200 \mathrm{~m}^{2}$ 程度以下の建物では，この 下限值はより高いものとなる。むた，図一2（b）によれ ば，辺長比 $(a / b)$ が 1.5 以上では建物の長さに関係な く，その值はそれぞれ $20^{\prime}$ および $30^{\prime}$ である。

ところで，上部構造に亀裂が発生する不同沈下量の大 きさは，通常の長期不同沈下に対する研究によれば， 1/500 あるいは 1/300 程度とされているが（例えば文献 4), この調查結果はそれを大きく上まわり，加多くの 建物はより大きな不同沈下が生じたにもかかわらず，上 部構造は無傷であった。このような状況は図一3をみる とよくわかる。すなわち，図一3 造を含む) 建物の被害状況を, その程度によって区分し た度数分布である。10'すなわら約 $3 / 1000$ ラジアン未満括よび最大 $10 \mathrm{~cm}$ 未满の沈下 で，かつ上部構造になんらの損傷がみられ なかった建物を無被害とすれば，被害棟数 は 425-110=315 棟となり，上記，被害棟 数比は約 $20.6 \%$ になる。この比率は当時 大崎 ${ }^{1)}$ が示した数值, 約 $20 \%$ (被害棟数 : 約 310 楝）に近いものである。なおここ に示した 425 棟は全数を 1530 棟とすれ
ば，その約 $28 \%$ に過ぎないが，被害をらけた建物のほ とんぞ全てが含まれている。また，特に大規模な液状化 が発生したと考学られる地域内では, ほぽしっ皆的な調 查が行われたとみなせるから，上記集計をこの範囲内に 限定すれば，256 棟中 236 棟，すなわち扔扔よそ $90 \%$ 強の $\mathrm{R} \mathrm{C}$ 造建物が前述した程度以上の被害をらけたこと になる。

ところで, 壁のみならずラーメンにまで亀裂が認めら

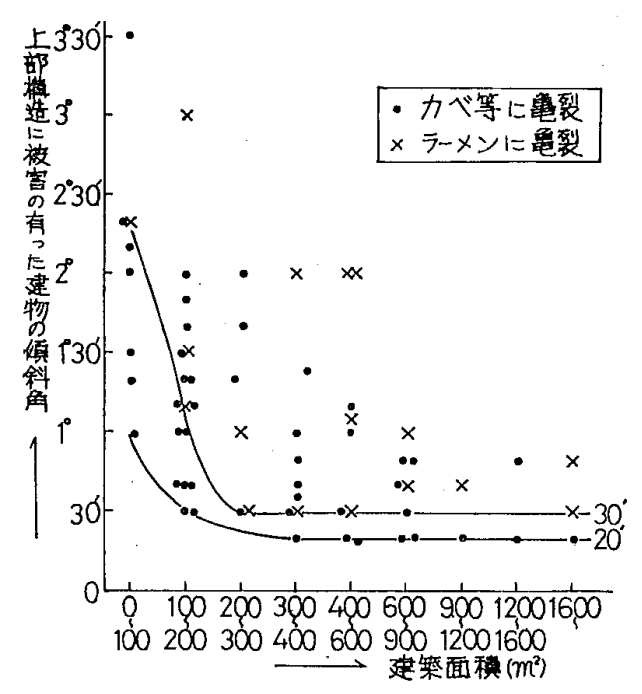

図一2（a） 建築面積之上部構造に損傷を
与えた䪸斜角の関係

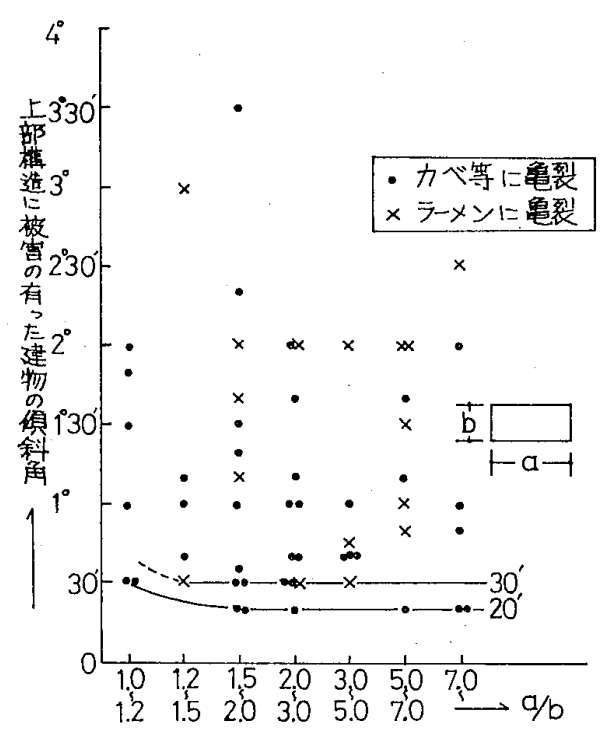

图一2（b）建物の長・短辺の比と上部構造に 損傷を与えた傾斜角の関係

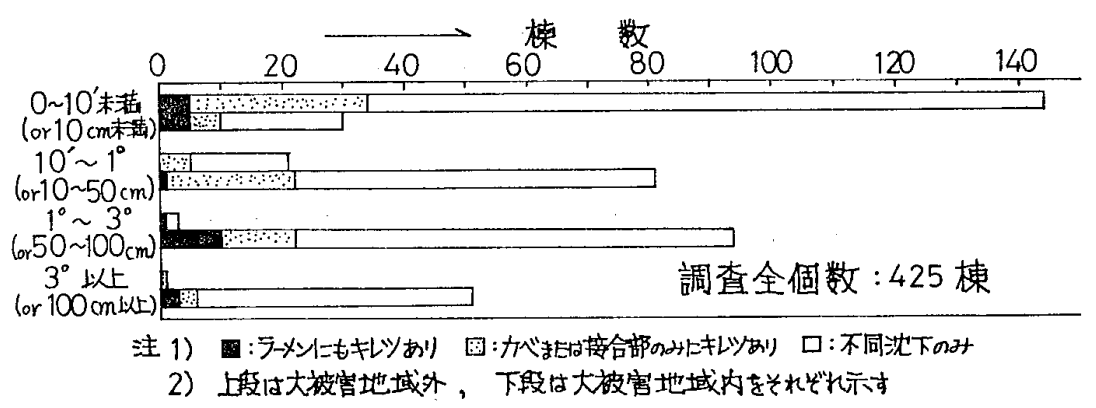

图一3 R C 造 (SRC 造定含を) 建物の被害度数分布 


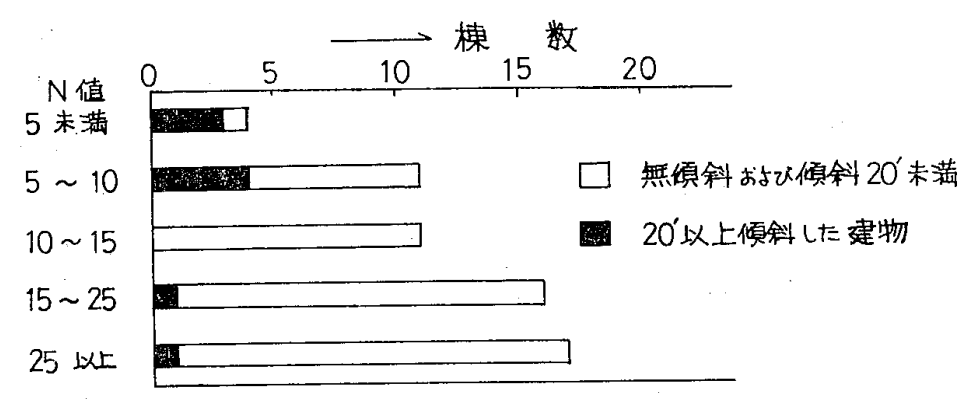

図一4（a） $\mathrm{R} \mathrm{C}$ 造建物の基礎先端 $N$ 值と被害（大被害地域外）

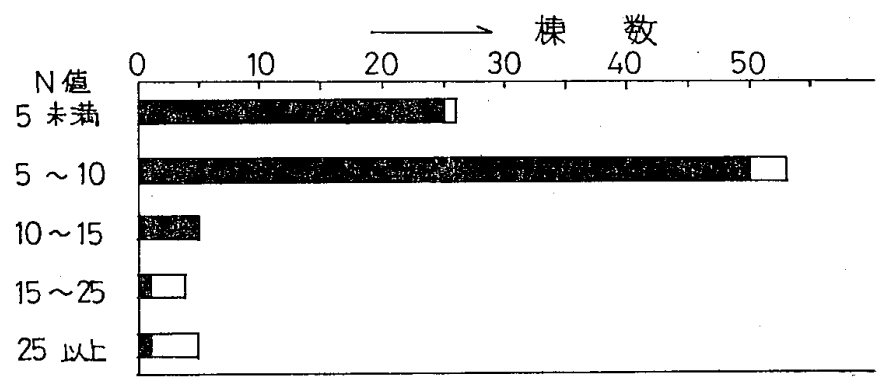

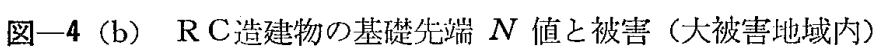

れた建物が 24 棟，壁あるいは接合部（エクスパンショ ンジョイントなど) のみに亀裂が生じたもの 76 棟, 合 計 100 棟が上部構造にも被害をらけたことになるがう ち大亀裂がみられたものは 30 棟程度であり, 他の 70 棟 は建物自身の損傷としては轻微であった。すなおち，上 部建物にも大亀裂がみられた建物は全数 (1530 棟)のお 拉よそ $2 \%$ 程度であり，被害の大部分は不同沈下である ことがわかる。

ここで, 図一1 の被害と基䃈下端付近の地層の $N$ 值 の関係を地域を分けて考えてみる。图一4（a)，(b) は基 礎下端付近 $1.0 \mathrm{~m}$ の平均 $N$ 值と, その地層によって支 持されている建物の被害の関係を, 大被害地域(後述) と それ以外の地域に分けて示したものである。両図とも $20^{\prime}$ の傾斜が，ほぼ不同沈下に基づく上部構造の被害の 限界となっていることから, 被害のあり, なしをその傾 斜角で区分している。図一4 (b) によれば, 大被害地域 では $N$ 值が 15 程度以上にならないと被害率は減少し ない。一方, 大被害地域外では, $N$ 值が 5 10 程度で も被害率は小さい。前述したように, 調查は被害密集地 域を中心として行われて抢り, 大被害地域外では, 被害 のタられる建物が主体となっている。したがって，しっ 皆調查が行われたとすれば, 大被害の無傾斜の比率は, はるかに高い比率となり上記の差異はより顕著になるこ とが推測される。

（2）被害と地盤構成の関係について

前述したように建物の被害状沉は地域によってかなり 異なり, 特に大きな被害は比較的新しい地盤上の市街地 に集中していた。記録5によよれば，この新しい堆積ある いは人工造成地は 1964 年の地震が大きな地震としては 初めての体験であった。
よく知られているように，ある規模以上の地震に よる振動作用をらける毎に驰い砂質地盤活密度を増 乙安定化に向う。この密度増加，すなわち砂粒子構 造の間隚の減少化の過程において，それが水で飽和 していれば，過剰の間隙水圧を生じ，静水圧に釣合 ら状態に至る間, 液状化する可能性をむつことにな る。5）によれば，文政 11 年（1832 年）の地震の 際にも，砂，水の噴き上げの現象がかなり生じたと のことである。ただし, 1964 年の地震で大被害をう けた地域の多くの部分は当時まだ陸地ではない。と ころで, 比較的近接した地域間の被害状況の差異に 関する地層状態, 地業等の面からの検討において, 次の 2 点が特に問題になった。

（i）比較的古くから陸地であったところでは被 害は少ない。しかし，そのような地域でも地表近く の数 $\mathrm{m}(4 \sim 5 \mathrm{~m})$ は弛い地層である場合も多く, か つ, 地下水位下にある層厚が 1 3 $\mathrm{m}$ 程度はある。

(ii )この旧陸地内の建物で直接基礎あるい短 いくい基礎で支持されている場合の支持地盤は，上記の ことから必らずしも良好な地層とはいえない。しかし， 大きな被害はほとんどうけていない。

このような現象を説明するために, 地震前後の同一地 点（あるいは近接地点）のボーリング資料汃ら, 深さと $N$ 值, またその值の地震による変化を検討し被害の地 域差と地層構成の関係の定量化を試みた ${ }^{6)}$ 。それは (1) 式および図一 5 で表わされる。

$$
N_{L}=1.35 x+0.4 \text {. }
$$

ここに, $x$ は媣さ $(\mathrm{m}), N_{L}$ は限界 $N$ 值である。す なわち, $x(\mathrm{~m})$ 深さの地震前 $N$ 值が $N_{L}$ 以下の場合, その深さの砂層は液状化した可能性をむつということに

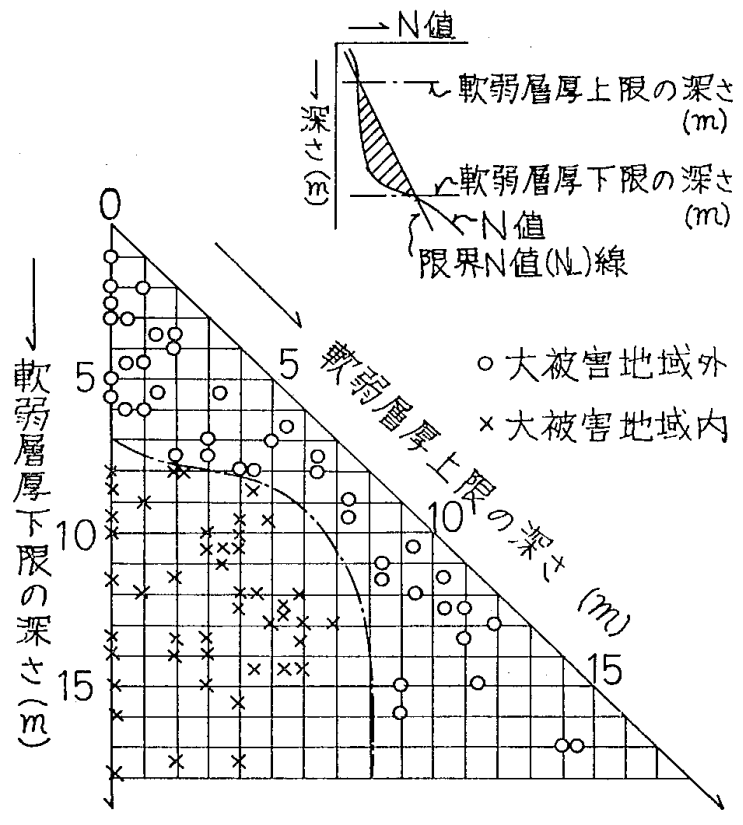

図一5 $N<N_{L}$ の砂層の存在深さ, 層厚と 被害の地域差の関係 
なる。なお，限界 $N$ 值と哚さの関係については小泉”の 提案がよく知られているが，(1) 式も本質的にはそれと 異なるものではない。ところで，前記 (i)，(ii) の現象， すなわち被害と地盤の関係は（1）式を用いた図一5の 表現によってかなり明確になる。すなわち，因一5は， 如何なる媣さにどの程度の $N_{L}$ 以下の砂層が存在した場 合に, 大規模な液状化 (大被害) が生じたかを示す。図 で $45^{\circ}$ の軸から点（○または $\times$ 印）までの縦軸に平行な 距離は, その地点の地層の地震前 $N$ 值が $N_{L}$ を下まわ る層厚を表わす。すなわち, 説明図のハッチ部分の層厚 である。図によれば， $N<N_{L}$ の層の上限の深さ $4,5 \mathrm{~m}$ および同下限の媣さ $8,9 \mathrm{~m}$ 地域では, $N<N_{L}$ の層厚 が $4 \mathrm{~m}$ 程度でも大被害が起きている。すなわち, 大被 害地域内のボーリング柱状図に対态する図中の×印の範 囲内に含まれることを意味する。一方, 地表面から GL$5,6 \mathrm{~m}$ 程度まで $N<N_{L}$ であっても, 大被害地域には なっていないが，それらの柱状図を個々に検討してみる と, 地下水位上の $1 \sim 2 \mathrm{~m}$ の層厚を差引いた $4 \mathrm{~m}$ 内外の 地層のうち, 通常の分類法で砂層に 属する部分は $2 \mathrm{~m}$ 程度の場合が多く, 残りはシルトあるいは粘土の薄層よ り成る。

以上より，大規模な液状化が生じたと考えられる地域， すなわち大被害地域は地層的には図上の一点鎖線の左下 側の範囲に含ま机る地盤条件をもつ地域であったと，お およそ定義できよう。かくして定めた大被害地域を地図 上に示したものが図一6である。また, 図中には元禄年 代（約 240 年前）の陸地線を併記したが，既によくいわ れてきたように当時の信濃川流路と大被害地域の範国 は，かなり良く対応する。

なお，図一5 の表現法は，筆者の一人である望月が当 時大崎順彦博士の御指導のもとに示したものであるが, 大崎は同様な表現法と, 前記小泉の梁さと限界 $N$ 值の

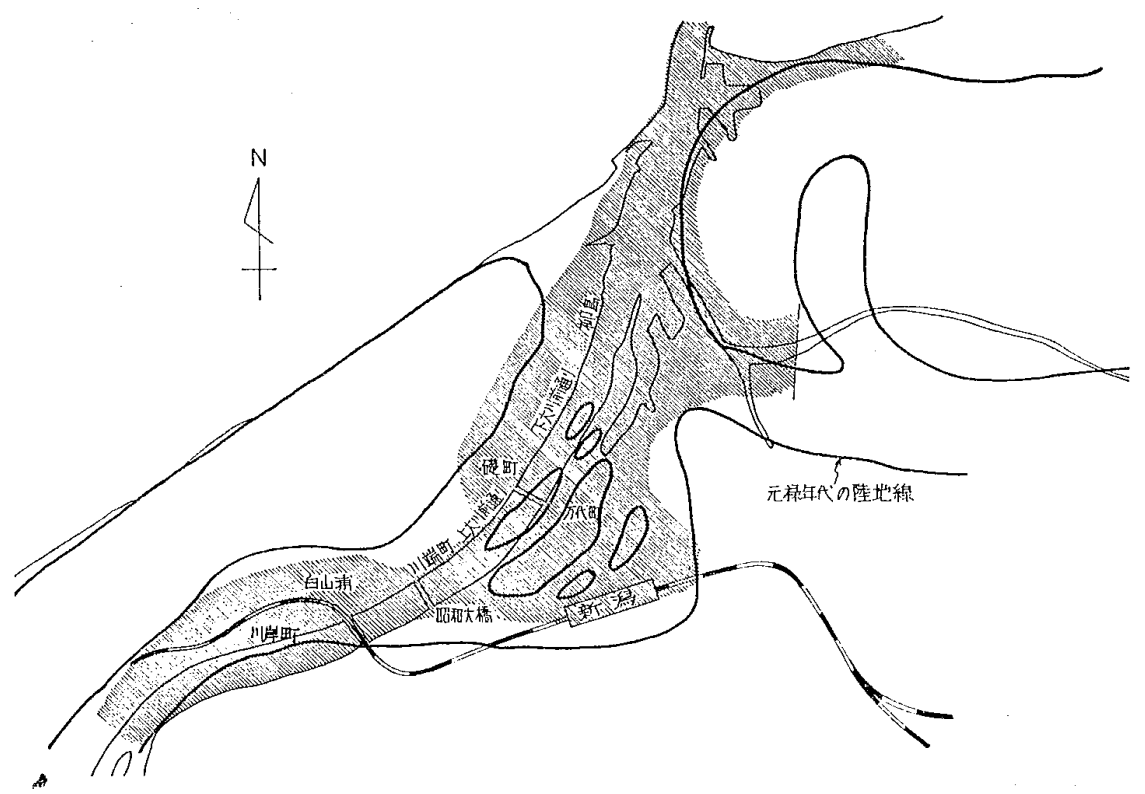

図一6 1964 年新潟地震による新潟书の大被害地域（図のハッチ部分）

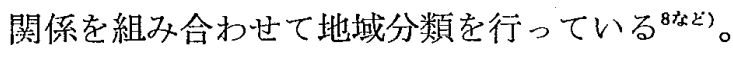

(3) 被害建物の復旧について

前記したように，液状化によるこの種の構造物の被害 の典型は沈下あるいはそれに基づく傾斜であり，多くは 上部構造に大きな損傷は生じていない。ところでこのの 地震の被害程度を表わす尺度として使われている沈下 量, 傾斜量は振動による半壞, 倒壞といった判定規準に 比べて，それらの量の意味するところが不明膫である。 また, 種々の地盤条件をむつ地域全体の被害想定を行ら 場合の共通の尺度としても適切ではない。そのような理 由から，ここで被害程度と被害金額を関連付け，液状 化に基づく被害をより一般化された形で評価しようとす る。

前記した地震当時の被災建物のらち, 比較的その程度 の著しい建物で，かつ所在地の判明しているものを選 び，アンケート調查を行った。明快な回答の得られた建 物は 45 棟に止ったが，これに文献 2) の資料を加え， 以下に幾つかの項目についてまとめて示す。

(i ) アンケートの回答拉よび文献 2) から, 比較的 被害が大きく，かつ地震後の状況が判明している 73 襕 の建物のらち，地震被害が直接の原因で全面的に取り壊 された建物は 11 棟である。それらはいずれも最大 100 $\mathrm{cm}$ 以上沈下しており, かつ $1^{\circ}$ 以上傾斜した建物であ る。

(ii） $130 \sim 150 \mathrm{~cm}$ 程度沈下を生じながら，ほとんど 修理せずにそのまま使用しているとの回答があった 3 棟 を除けば，抒打上そ $30 \mathrm{~cm}$ 以上の沈下，1内外以上の 傾斜を生じた建物は少なから始費用を投じて改修されて いる。図一7 は最大沈下量（傾斜角）と建物単位面積当 りの復旧費の関係であり, 復旧費は 2 万円 $/ \mathrm{m}^{2}$ 内外を中 心に分布している。また, 図から上記程度以上の被害を らけた建物についていえば, 被害規模と復旧費の間に一 定の関係は見出せない。

（iii） 図一8 は復旧費とその方法をお おまかに分類して示したものであるが， 建て起こされた多くの建物は単なる復旧 にとどまらず，基礎の補強を行っている ことがわかる。この場合の基礎の補強は セメントなどの注入によるグラウト，す なわち地盤改良あるいは鋼ぐいの圧入な どである。また，基本的に洞一工法に よる改修でもその費用には大きな愊があ るが，その詳細は分析できなかった。

（iv）図一9 注役費と建物新築当時 の総工費の両者が共に判明している建物 について，復旧費の建築費指数によって 換算された総工費に対する割合を最大沈 下量との関連で表わしたものである。す 
なわち，液状化による建物の地震被害を定量化するため の尺度として上記の比率を考えた。ここに建筑費指数と は，建設工業経営研究会“標準建築費指数”に示されて いる值で，建築工費の月間変動，年間変動がある月ある い注年度を標準 (100) として表わされている。それに従 って，図一9の R C造建物の建設年度により，総工費に 一定の指数を乗じ，復旧年度に相当する総工費を推定し

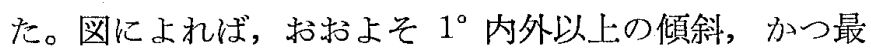
大 $30 \mathrm{~cm}$ 程度以上泌下した建物は，半壞ないしそれ以 上の被害をうけたとみなすことができよう。

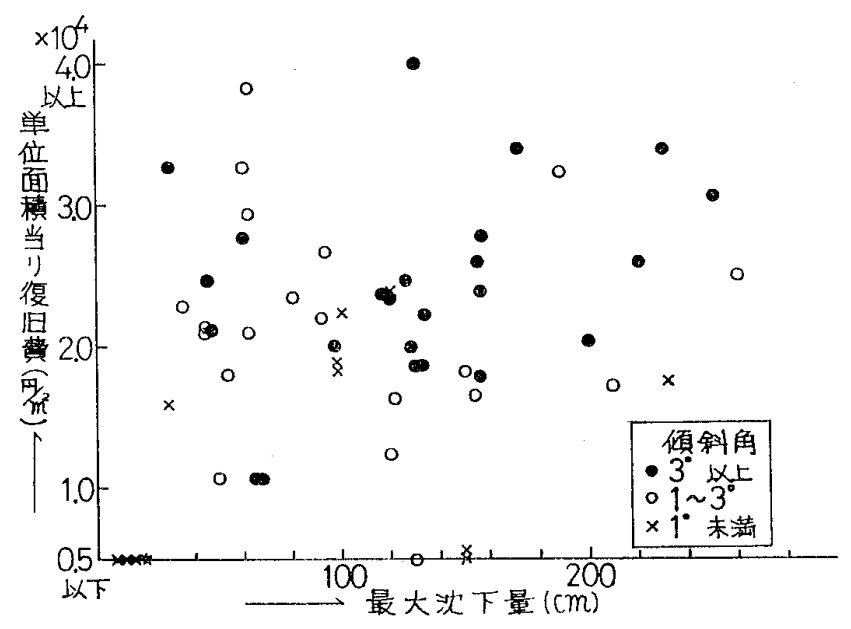

図-7 趎物の沈下・傾斜と復旧費の関係

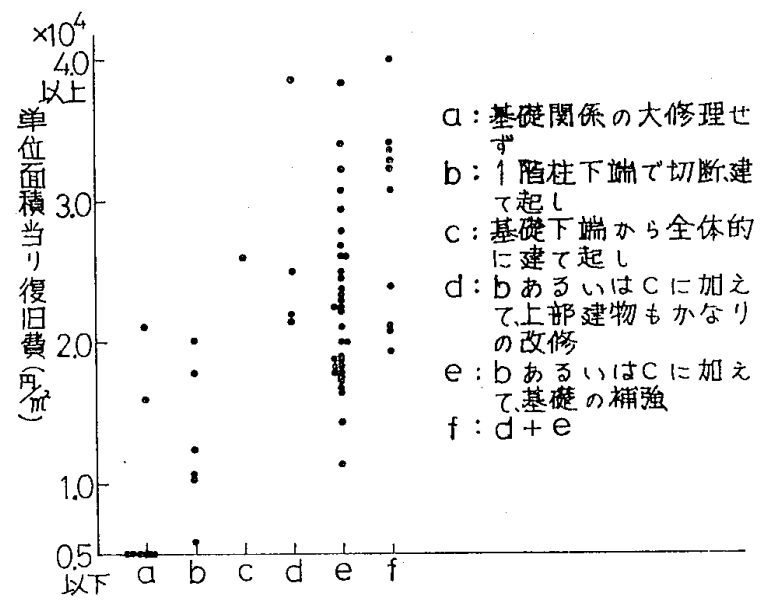

図一8 復旧方法と費用の関係

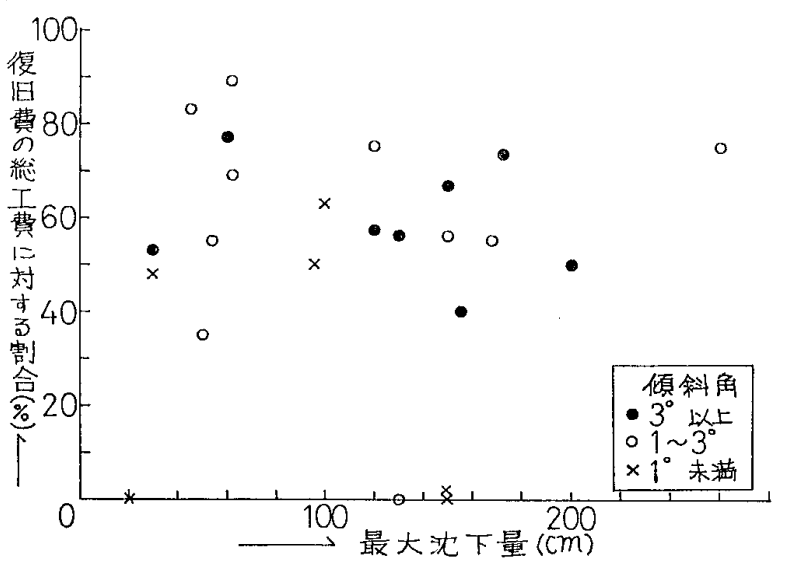

図一9 建物の沈下，傾斜と復旧費の総工費に対する割合 （v）以上の復旧に関する調査結果を基にして地震直 後の被害調查結果 (図一3) を考えてみる。大被害地域内 で，被害状沿の判明している建物総棟数は 256 棟であ り，前述したようにこの地域内の $\mathrm{R} \mathrm{C}$ 造建物のほとんぜ が含まれていると推察される。図一3によれば,このう ち 145 棟が $1^{\circ}$ 以上の傾斜, あるいは $50 \mathrm{~cm}$ 以上の沈下 を生じていることになるが，これを図一3，図一7，9 と 合わせてみると，大規模洨状化が発生したと考えられる 地域内に限定すれば，おおよそ $57 \%$ ないし，それ以上 の R C 造建物が半壊以上の被害をうけたと推定できよ 亏。

\section{3. 木造建物の被害とその復旧}

調查地域は，前記した目的から大被害地域，すなわち 図一6 の八ッチ部分の内で，当時から現在まで木造建物 が比較的まとまって存在する地区とした。地名でいえば 川岸町, 白山浦, 上大川, 川端町, 礎町, 万代町などで あり，現地に打ける聞き込み調查は昭和 50 年 9 月に行 った。

（1）地震直後の調査による被害率と復旧費

図-10は，各調查地区に打る建物調查棟数とそれぞ れの建物に対与る地震直後の市当局による全嬛，半懷な ごの判定加ら全壊率，被害率 $=($ 全壊棟数 $+0.5 \times$ 半壊棟 数)/全棟数（\%) 党推定したものである。な打, 新潟市 内各地区の地域別全壊率，被害率を算出しらるような資 料は，市，県当局で性見出すことができなかった。それ 故，この集計は著者らの調査棟数を母数として扔り，少 ンプリング調查による推定といらことになるが，いずれ の地区に拉いても被害率は極めて高い。その内訳をみる と, 半壞との回答が著しく高く, 白山浦の $48.2 \%$ から 上大川，川端町の $66.7 \%$ まで，また全体では $56.9 \%$ が これに相当する。全壊率は川岸町の $18.5 \%$ 加ら上小， 川端町の $7.1 \%$ までの間にあり，全体では $12.3 \%$ とな る。ところで, 半壊の回答に打ける被圊内容扝よび後述
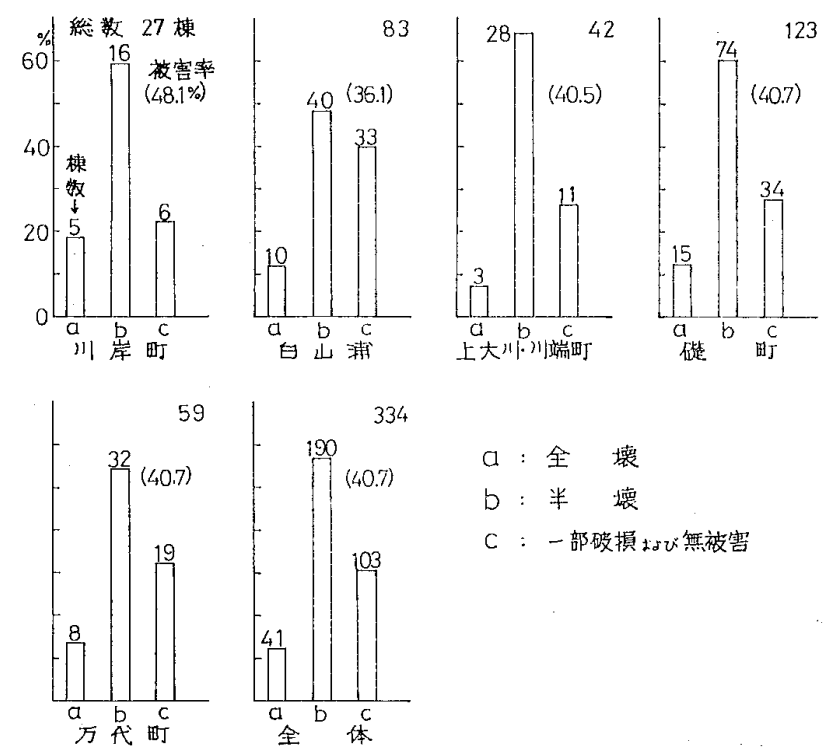

@：全 壇

b : 半噮

C：一部破䪱沵ひ無被害

図一10 地震直後の当局り判定による被害棟数分布 


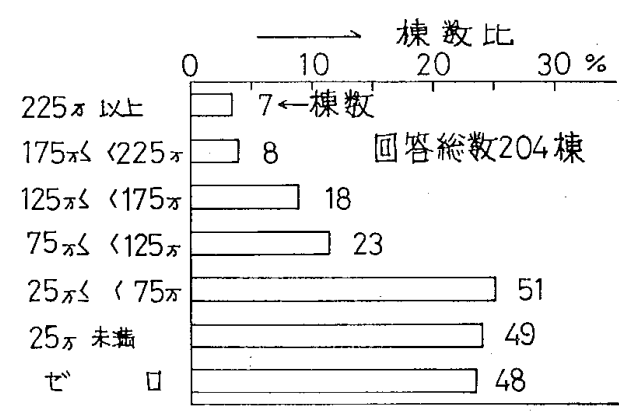

图-11:修理費（全体）

の復汨費（被害金額）には大きな幅があり，検討の必要 はあるが，上記の結果からみて地盤の液状化による木造 建物の被害は，半壊型が多数を占めるといえよう。

図一11 は，復旧費（1964１965 年当時の金額）につ いて回答のあった 204 棟の建物に対して，その金額によ り 7 段階に区分して表わしたものである。金額ゼロが 204 棟のうちの $36.5 \%$ で, 当時一部破損または無被害 と判定された棟数比 $30.8 \%$ を越える。また， 25 万円未 満（その多くは 10 万円内外）を合わせれば， $47.6 \%$ と なり，半壊棟数の $30 \%$ 弱がこれに含まれる。この上う に被害金額（復旧費）の点加らみても半壊には大きな幅 のあることがわかる。次にこの復旧費の主な使途につい て概略する。

（i） 沈下あるいは噴砂などで不同になった敷地の整 地。この際，砂を搬入した場合と逆に搬出した場合があ り，いずれもその量が極めて多い建物ではトラック数 台〜十数台に達する。また, 敷地地盤がゆるんでしまっ た例も少なからずみられ，泥砂を取り除き新しい砂と入 れかえている。

（ii） 建物の沈下部分のジャッキによる建て起こしと 基礎の打ち直し。骨組，建具のひずみ直し，壁の補修。

（iii）浸水によるタタミ, 建具, 壁などの損傷に対す る補修など。

（2）被害状況と被害率の検討

液状化を完全な砂と水との混合液体一の移行とみれ 吕その比重から考えて，木造建物の上らに軽い建物が その中に大きく沈下することは考えにくい。図一12 は 建物の最大沈下量を 6 段階に区分して示したものであ る。図によれば, 最大沈下量が $180 \mathrm{~cm}$ 以上の建物が 3 棟あり，これを含め同 $70 \mathrm{~cm}$ 以上が回答総数 (209 植) の $12.8 \%$ を占める。そして，回答の中には家がゆれな がら徐々に沈んでいったとの明確な発言もある。また， 地震直後の現地調查において大きく沈下した木造建物の 写真も記録されている(例えば, 文献 3 )。このよらな 木造建物の沈下は次のよらな現象によって生じたと推測 する。

（i）建物直下あるいはその付近の地盤の液状化によ り, 基礎周囲に噴砂, 噴泥が生じ，その部分の地耐力が 大幅に低下した。噴砂, 噴泥が生じた部分およびその近

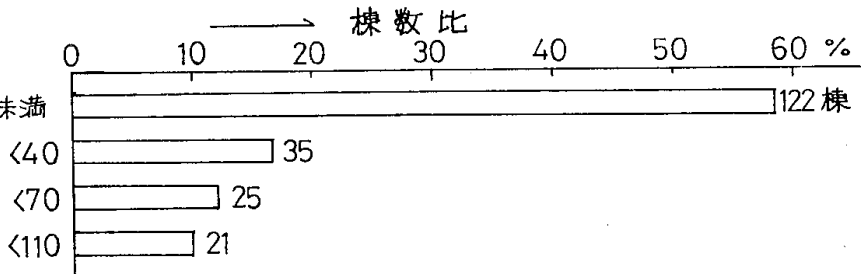

総 数 209 棵
図-12 基礎最大沈下量

辺の地盤は著しくゆるんだと考えられ，木造建物でも長 期間沈下が進行したとの回答，あるいは地盤がゆるんで 基整が打てないため，建物下の土を大規模に交換したな どの回答が得られている。そして, 以上の現象が建物下 全体にわた机ば，全体的な沈下を生ずるであるうし，局 部的な場合には不同沈下が起こる。

（ii） 液状化が生じた場合，その部分の地盤は最終的 には沈下すると考えられるが，これが不同の場合，建物 被害からみれば不同沈下の型をとる。

（iii）建物全体からみれば不同な地すべり的上の横移 動

（iv）建物下地盤の全体的あるいは局部的な宿没

（v） 基礎直下あるいはその周辺の大きな地割れ などで㐫りこれれらの現象（原因）が幾つか重疊したこ とも十分考えられる。

図一13 注当時全壊と判定された 41 楝の建物の主な被 害状況あるいは被害原因による内訳である。 $\mathrm{R} \mathrm{C}$ 造建物 の場合と同様に被害をうけた木造建物の多くは，上部構 造などに大きな損傷はないまま，不同沈下，傾斜を生じ たといえるが (図一12)，全壊建物のなかで特徵的なこ とは，地割れ，局部的な陌没による建物の破断が目立つ 点にある。この被害型は建物の主要部分に㧍いて, 基礎 から屋根に至るまで家が垂直に引き裂かれ，その傷口が V型ないし逆V型をなすもので，多くは後者の型のよう である。そして, 基礎の分離幅と地割れの幅がほぼ一致 していたと回答されたケースもあり，また，大きな地割 れが建物直下に 2 本生じ, 家が 2 ケ所で分離してしま。 た等の回答もある。図一13 では，この被害型が 14 棟， 約 34\% を占める。

そ机に次ぐ全壊建物は著しい不同沈下（傾斜）によっ て生じて㧍り，上記と同様の比率でいって，27\% 弱を示

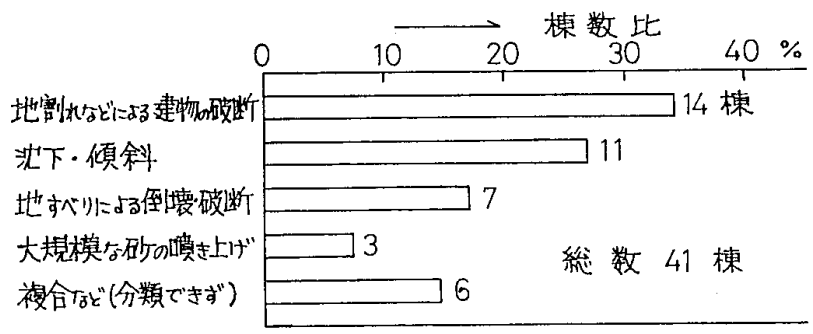

図一13筑全壊建物の被害状況（原因） 

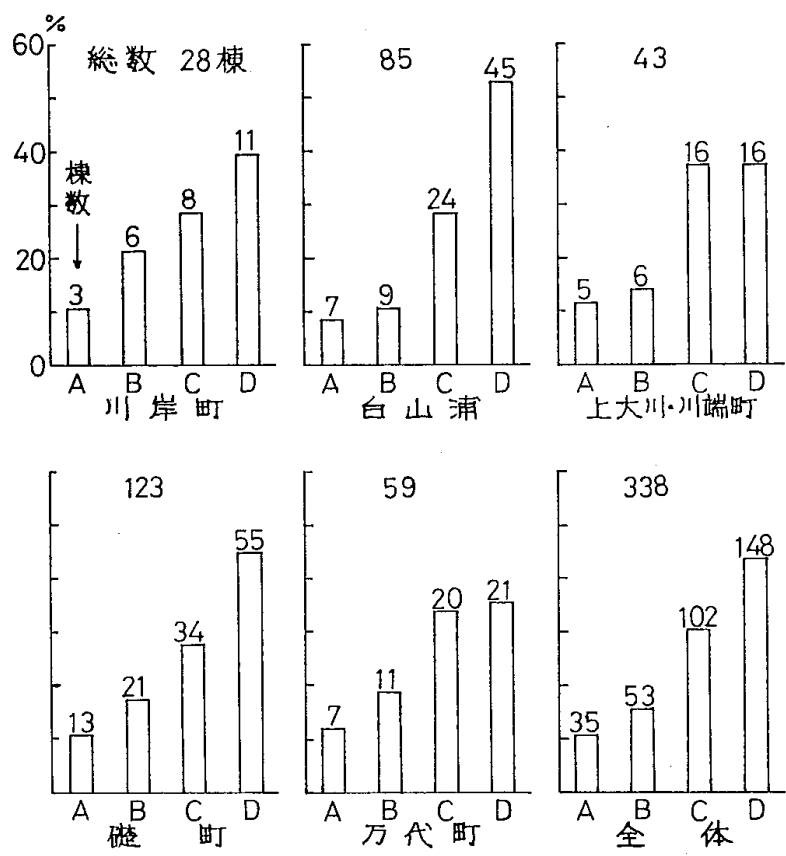

図一14 統合判定による建物被害階級分布

す。その他，地すべりによって骨組に大きなひずみが生 し，1 階が倒壞した建物，同様にして基礁の不同な移動 のため破断した建物などが約 $17 \%$ (7 棟)，建物内抢よ びその周辺に大規模な砂の噴き上げが生じたことによる 損傷から全壊と判定された建物などであり，この著しい ものとしては天井まで砂が噴き上げたという。

ところで，今回の調查によれば，地震当時全壊と判定 された 41 鄱の建物のらち，地震被害が直接の原因で取 り壊わされた建物は 11 棟に過ぎない。また，前述した ように被害金額からみても，半壞の内訳は大きな幅をも っている。それで，被害程度にやや体系的な基淮を設け て被害階級区分を行い，被害程度と建物性状あるいは建 物周囲の地盤性状（地変）などとの関係を検討すること にした。

図一14 は表一1 に示した被害程度判定の基本的な目 安をもとにしこれに建物の傾斜，きれつ，ひずみなど の被害に関する諸項目の回答を加味して A, B, C, D の
4 階級に被害程度を再区分したときの各地区、抢よび調查. 地区全体の棟数分布である。この判定法によれば，全壊 またはそれに準ずる大被害 A に属する建物は 35 棟，約 $10.5 \%$ となり，当時の全壊判定棟数（比），41 棟（約 12.3\%）上り若干低下寸ることになる。一方，当時の判 定による 190 棟の半壊建物は被害階級 B, C のみならず， 軽微な被害または無被害のDへも一部は移行している。 被害判定，特に半壞には十分明確な共通定義はないよう に思われるが，文字通り復旧に際して，建物を再建（新 築) する場合の招㧤よそ $1 / 2$ 程度の費用を要する被害と 考えれば，ここでいう被害階級 B 程度の被害といえよ う。そのような仮定のもとでは $\mathrm{A}$ を全壤として，全調查 地区の招扮まかな被害率桜約 $18.2 \%$ に低下寸る。その 結果として軽微な被害の建物が大幅に増え，図一10の度 数分布とはかなり異なった棟数分布となる（図-14）。

（3）被害と地割れ・噴砂打よび建物諸性状との関係 図一15 は建物直下の地割れのあり，なし（不明を含 む）と被害の関係である。前述したように，当時全壊と 判定された建物の最大多数は建物の破断であり，図一15 に掠いても建物直下の地割れが建物の大被害に少なから ず影響していることがわかる。ところで，これらの地割 れの直接の発生原因は種々考光られるが，その根源をな すものは地盤の液状化にあると推察している。すなわ ち，地割れからの噴砂，噴水が認められて扔り，またそ の方向む多くの場合様々である。そして，地すべり等に 伴う場合であっても，ほとんど平坦地ともいえる地盤に おける土の移動は，それが通常状態にある場合には生じ にくい現象といえよう。

図一16 は建物直下に扝汀る噴砂のあり，なし（不明 を含む) と被害の関係である。図のなしおよび不明は直 下にはないが，周囲にはあり：118 棟, 全く認められず： 15 棟，不明：77 棟である。したがって，建物の直下に 噴砂の認められたもの $38 \%$ に，周囲で認められたもの を加えれば，調查総数の約 $73 \%$ に達し，地表での噴砂 現象を妨げる可能性のある地表付近の粘性土層（不透水

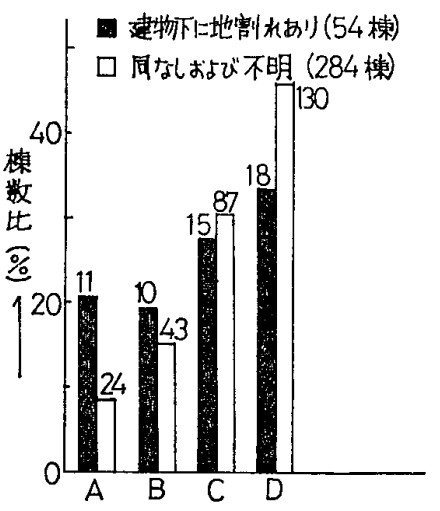

図一15建物直下の地割れと 被害の関係

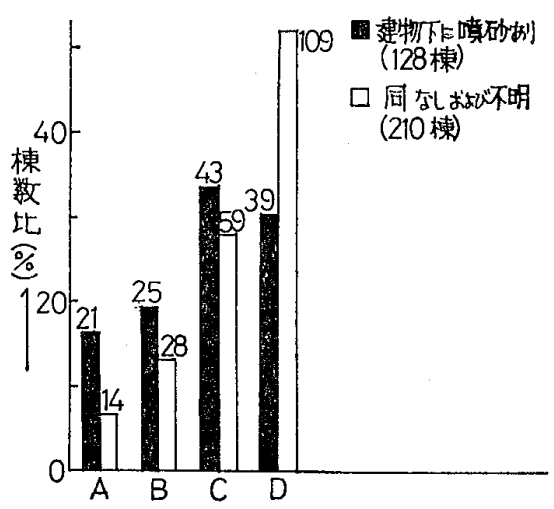

図一16 建物直下の噴砂己 被害の関係

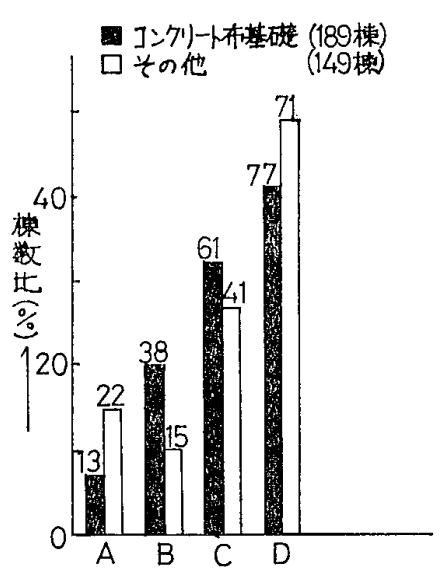

図-17 基礎形式と 被害の関係 
層）の存在を考えれば,こごで刘象としている地城の地 盤は大部分液状化したと推測できよう。そして，噴砂は 地割れと同程度に建物の被害に影響していることが図一 15，16 からわかる。なお，地割秃と櫴砂が建物直下で 共に生じたとの回答は 37 禑あり,これに限孔ばA：9 棟（約 24\%），B：8棟（約 22\%）となり，大被害の比 率汢上り高く現わ扎る。

ところで，このような地変による被害に刘し，建物性 状がどのような関係をもっていたかを知るために，まず 図一17 に基礎形式と被害の関係を示した。被害階級 A についてはコンクリート布基礎が他の基礎（ほとんぞが 土台石による独立基礎）に比べて比率は減じているが， Bではもはや逆転して抢り，全体的にみてコンクリート 布基礎と他の基礎との間に優劣は認められない。結局, 一体式の連続基礎であっても, 通常の無筋コンクリート 基礎の場合，液状化による被害を軽減させる効果はない といえよう。

な㧍, この調查では建物用途, 面積, 階数, 建築年度 などの区分も行っているが，用途で住宅以外の建物が， また用途との関連もあって建築面積の大なるものほど被 害程度がやや高くなる傾向が認められた程度で，他の建 物性状と被害の間には一定の関係はみられなかった。

このような点は通常の振動被害と汪異なるところと思 われ，地変の発生とその程度が被害規模を決定的に支配 し，建物の老朽度，階数差などはほとんど表に現わ机て きていない。すなわち，極好て过い範囲内，例えば隣 合ら建物同志むるいは住宅地内の道路一本はさんだ建物 間に押いてを著しい被害の差異の夕られる場合が少なか らずありここれらのほとんどが建物の面からは全く説明 が付かない。そして，このように極めてミク口な地域的 被害差がまた液状化による木造建物群の被害型の大きな 特徴の一つと考えられる。

\section{4. 地盤・建物の振動を推測させる 2，3 の事象}

県営川岸町アパートの強震記録の NS 成分について大 岡 ${ }^{93}$ は興味ある推測を行っている。すなわち，隣合う建 物閒隔を容器の奥行とする液状化した流体のスロッシン グではないかとの見方であり，液状化のメカニズムと上 記流体のスロッシングの固有周期が約 5.5 秒になること などを推測基盤としている。このような観点から EW 成分（例えば，文献 10）をみると，NS 成分とほぼ同時: に最大加速度值を示しているが，この方向は建物長辺方 向であり，建物配列からみて自由地表面が連続するため， 大岡がスロッシングと推察しているよらな顕著な波はみ られない。そして，ほぼ 1 波の高レベル（最大加速度 $159 \mathrm{gal})$ の加速度波の後は急激にその振幅を減じてい る。すなわち，液状化により地表面付近の砂層のせん断 剛性が著しく低下し，S波が地表まで伝達されにくくな っている状況を思わせる。

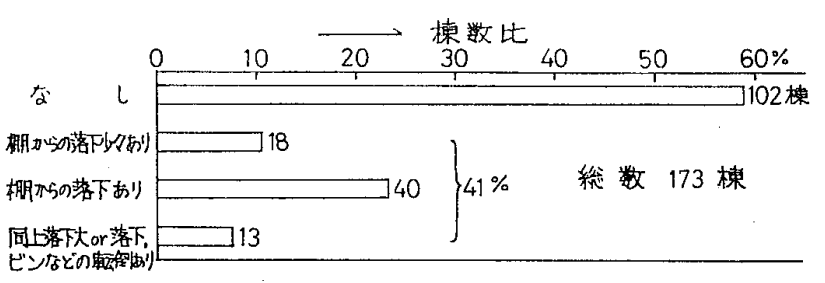

图一18 建物内に打ける器物の落下, 転倒の状況

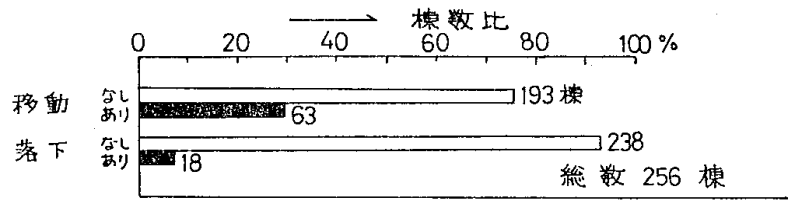

図一19 屋根瓦の移動・落下

このよらな液状化地域の建物（地盤）の振動状況を推 測するた如に，建物内の器物の落下，転倒状沉を調べた 結果が図一18 である。屯た，それとの関連で屋根瓦の 移動あるいは落下についてまとめたものが図一19 であ る。図一18 によ机ば，回答総数の $59 \%$ が器物の落下， 転倒を否定している。残りの $41 \%$ の回答の中には建物 が著しく傾いたり，破断したことによって生じたと考え られる場合も含まれているから，直接振動によると推察 される比率はより低下するはずで岁る。また，通常の家 具などの振動によると思われる転倒はほとんど生じなか ったよらである。すなわち，主として液状化地域内の地 震動加速度毦想像以上に低かったたといえ，これはまた 屋根瓦の被害の程度からも推測できる。

以上は示唆に富む現象であり, $\mathrm{S}$ 波による振動と液状 化による耐力, 支持力低下の両者が同時に，かつ破壞的 に構造物に作用することは考えなくてよいのではなかろ らか。いいかえれば，地域の地震時被害想定などにおい て, 振動による被害危険度と地盤の液状化による被害危 険度を重複させて考える必要はない上うに思わ机る。

\section{5. ま め}

（1） 1964 年新潟地震による新潟市とその近郊にお けるR C (SRC を含む) 造建物の被害は, 総数約 1530 棟のらち約 315 棟（約 $20 \%$ 強）に及ぶ。なお，ここに いら被害は，傾斜 $10^{\prime}(\doteqdot 3 / 1000)$ 以上, 最大 $10 \mathrm{~cm}$ 以上 の沈下あるいは上部構造に損傷がみられる場合である。

（2）上記の建物のほとんどは沈下，傾斜およびそれ に伴ら建物損傷であるが，建物損傷と不同沈下量の関係 は，建築面積が $200 \mathrm{~m}^{2}$ 程度以下の小規模な建物を除き， 壁などに亀裂が生じた不同沈下量の下限は約 $20^{\prime}(\doteqdot 3 /$ 500)，またラーメン材にまで亀裂が生じた同下限江 $30^{\prime}$ (

（3）被害方密集した大被害地域(大規模液状化地域) は，次の限界 $N$ 值 $\left(N_{L}\right)$ と深さ $(x \mathrm{~m})$ の関係式, $N_{L}$ $=1.35 x+0.4$ と, それを地震前の各地域のボーリング 柱状図に対応させた図一5により，低被害地城と区分で きる。 
（4）（3）の大被害地域内に限定すれば，(1）の被害 棟数比は, 打打よそ $90 \%$ 強と推測される。

（5）復旧工法およびそれに要した費用からみて，お およそ $1^{\circ}$ 内外以上の傾斜，加最大 $30 \mathrm{~cm}$ 程度以上沈 下した R C造建物は半壊ないしそれ以上の被慧をらけた と見なしらる。

（6）（5）について，大被害地域に限定すれば，おお よそ $57 \%$ の R C造建物が半壞以上の被害をらけたと推 定される。

（7）当時の被害判定による大被害地域内の木造建物 の全壊率は $12.3 \%$ ，半環率は $57 \%$ 程度と推定される。 したがって，被害率は $40.7 \%$ となるが，特に半壊の内 容は様々であり，被害程度に大きな愊がある。

（8）全壞木造建物の主な被害型（原因）は液状化に 起因すると思われる地割れなどによる建物の破断，大規 模な沈下，傾斜，地すべりによる倒壊，破断，大規模な 砂の噴き上げによるものなどである。

（9）修理費，沈下量，傾斜，亀裂（破断）などから 総合的に被害程度を判定した結果によれば，木造建物の 全壊率は $10.5 \%$ ，被害率は $18.2 \%$ 程度し推定され，こ こで行った被害再区分がほぼ妥当な值を示していると考 えている。

（10）液状化による木造建物群の被害型の大きな特徵 と考えられるが，建物㨁下の地割れ，噴砂のありなしな どが被害と高い相関性をもっておう，これらがせまい地 域内に打ける個々の木造建物の被害程度の差として現わ れている。

（11）一体式のコンクリート布基礎であって\&，無筋 の場合，液状化による被害を軽減しえない。すなわち， コンクリート布基礎とそれ以外の基礎をもつ建物の閒に 被害差は見出せない。また, 階数, 老柯度と被害程度の 間にも一定の関係はみられない。この点は通常の振動被 害とは異なる点と思われる。

（12）建物内の器物の落下，転倒状況，屋根瓦の移動
落下などの調查結果からみても液状化地域内の地震加速 度は想像以上に低かったと推測される。また，建物の被 害状況，強震記録などから，全く推論ではあるが，振動 被害と液状化による被害を同時に重曽して考它る必要は ないように思われる。

\section{謝辞}

本報告に㧍ける最近の現地調查は東京都防災会議直下 型地震に関する調査研究の一環として奏施した。関係各 位ならびに新潟市で打世話になった方及に深謝いたしま す。また，地震当時の調查，整理で御涝力いただいた砳 宵室の方々および御指導, 御助言いただいた現東京大学 大崎順彦教授に愿く御礼申し上げます。

さらに, 今回現地調查などで行動を共にされた東京都 立大学工学部国井隆弘助教授, 同理学部松田磐余助教授 他および本報告をまとめるに際し終始御指導いただいた 神奈川大学田治米辰雄教授に深謝の意を表わす次第で क。

\section{引用 文 献}

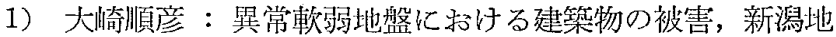
震防災研究総合報告会，科学技術庁国立防災科学技術七 ンター，全国科学技術連合，1964 年 8 月

2）日本建築学会：震害建物復旧の記録一新潟地震で被災し た鉄筋コンクリート建物一，昭和 41 年 4 月

3) 日本建築学会 : 新潟地震災害調査報告, 昭和 39 年 12 月

4）大崎順彦：基礎橉造，コ口十社，昭和 36 年初刊

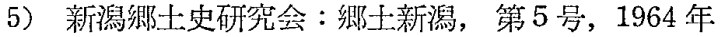

6）田治米辰雄, 望月利男 : On the Liquefaction of Saturated Sand in Niigata Earthquake, 東京都立大学工学 部報告, No. 15, 1965 年

7）小泉安則：新潟地震における砂の密度の変化, 土と基礎, Vol. 13, No. 2, 1965

8) Yorihiko Ohsaki : Niigata Earthquakes, 1964 Building Damage and Soil Condition, Soil and Foundation, Vol. VI, No. 2, March 1966

9）大阊 弘：新潟地震における県営川岸町アパートの振動・ 傾斜性状についての一考察，昭和 50 年度日本建築学会関 東支部研究報告集 <棈造系>

10）学術文献普及社：Digitized Strong-Motion Earthquake Accelerograms in Japan, 1972 


\section{S Y N OPSIS}

U.D.C. $550.34: 624.131 .2$

ON THE DAMAGE OF BUILDING BY LIQUEFACTION OF GROUND

- From Survey on the Damage by the Niigata Earthquake, 1964 and Restoration of Building in Niigata City-

by Dr. TOSHIO MOCHIZUKI and MICHIO MIYANO, Members of A.I.J.

This paper describes the damages of buildings caused by liquefaction of ground on the Niigata Earthquake, 1964 . In the first place, we examined the investigated data which we surveyed immediately after the Earthquake and recently. Then we assumed the damage rate of wooden or $\mathrm{RC}$ buildings.

As a result, it is found that in the large damaged area, 57\% RC building got larger damages and the damage rate of wooden buildings was $40.7 \%$.

Further, it is assumed that in the liquefied area, the earthquake acceleration was lower, and the damages showed some peculiarity.

From these points of view, it is found that in case of assuming the earthquake danger of area, we need not overlap the danger by earthquake vibration and liquefaction of ground. 